\title{
Self-Esteem and Fixed Price in Islamic Law (A Critical Study of the Pesuke Tradition among the Nobles of the Sasak Tribe of Lombok)
}

\author{
Zaenudin Mansyur \\ Faculty of Sharia UIN Mataram, 100 Gajah Mada Pagesangan Street, Sekarbela \\ District, Mataram City, West Nusa Tenggara, \\ email: zain_nahwa@yahoo.com
}

Article history: Received: August 17, 2020, Accepted: May 15, 2021, Published: June 27, 2021

\begin{abstract}
:
The Sasak aristocracy in Lombok is still very passionate about carrying out the pesuke tradition. Although, the pesuke practice did not infrequently cause various conflicts between the prospective bride and groom's families. For instance, when the prospective bride's family sets the pesuke value that is too high, which can burden the groom's family. In contrast, religion forbids us to burden and encourages us to work together, help, and ease each other to create a happy and prosperous family in the world to the hereafter. Therefore, this study aims to examine how the perspective of Islamic law on the concept of self-esteem and fixed price in the pesuke tradition. The results showed that the motivation of the Sasak aristocratic community in setting a high pesuke value so that the public still respected their communal identity. In addition, another reason in determining the fantastic value of pesuke is to make it a fixed price in a marriage with melaik, meruput, or merugul systems. Therefore, the groom's family must pay this Pesuke as a ransom to restore the bride's family's dignity. Meanwhile, according to Islamic law, the pesuke tradition as a form of maintaining selfrespect and fixed price should be a tolerable case for the creation of a peaceful and prosperous marriage because of the emergence of mutual willingness and pleasure between the two parties, by the essence of pesuke, namely mutual desire.
\end{abstract}

Author correspondence email: zain_nahwa@yahoo.com Available online at: http:/ / ejournal.iainmadura.ac.id/index.php/alihkam/ Copyright (c) 2021 by al-ihkam. All Right Reserved 
Keywords:

Self-esteem; Fixed Price; Pesuke; Sasak Aristocratic

\begin{abstract}
Abstrak:
Kaum bangsawan Sasak di Lombok masih sangat fanatik dalam menjalankan tradisi pesuke. Meskipun, tradisi pesuke ini ternyata tidak jarang menimbulkan berbagai konflik antara kedua keluarga calon mempelai. Misalnya, ketika keluarga calon mempelai wanita menetapkan nilai pesuke yang terlalu tinggi yang dapat memberatkan keluarga calon mempelai pria. Padahal, agama melarang untuk saling memberatkan dan menganjurkan untuk saling tolong menolong, meringankan, dan bahu membahu agar tercipta keluarga yang bahagia dan sejahtera dunia akhirat. Oleh karena itu, penelitian ini bertujuan untuk mengkaji bagaimana perspektif hukum Islam tentang konsep harga diri dan harga mati dalam tradisi pesuke tersebut. Hasil penelitian menunjukkan bahwa, motivasi masyarakat bangsawan Sasak dalam menetapkan nilai pesuke yang tinggi agar identitas komunal tetap dihargai oleh publik. Motivasi lain dalam penentuan nilai pesuke yang fantastis yaitu untuk menjadikannya sebagai harga mati dalam perkawinan yang dilangsungkan dengan sistem melaik, meruput, atau merugul. Pesuke ini harus dibayar oleh keluarga pria sebagai tebusan untuk mengembalikan marwah keluarga wanita. Sementara, menurut hukum Islam, tradisi pesuke sebagai wujud mempertahankan harga diri dan harga mati seharusnya menjadi perkara yang dapat ditolerir demi terciptanya perkawinan yang damai, dan sejahtera karena timbulnya kerelaan dan kesenangan diantara kedua belah pihak, sesuai dengan esensi pesuke, yaitu suka sama suka.
\end{abstract}

Kata Kunci:

Harga Diri; Harga Mati; Pesuke; Bangswan Sasak 


\section{Introduction}

The pesuke tradition applies to the Sasak people who inhabit the island of Lombok. ${ }^{1}$ This tradition is a phenomenal custom but contrary to the rules of marriage in Islam. ${ }^{2}$

Pesuke is a tradition of giving several goods or money from the male family to the female family according to mutual agreement. ${ }^{3}$ The giving of pesuke is very varied in quantity because it depends on the level of the social status of the bride and her family. ${ }^{4}$ Ordinary people (jajar karang) do not set pesuke tariffs like the Sasak aristocrats (pemenak).

Generally, the jajar karang community asks pesuke by adjusting the ability of the prospective groom after the bargaining process first. Although, there are also jajar karang women asking pesuke rates that resemble noblewomen. This phenomenon occurs in the jajar karang society who domiciled in the majority population area of the aristocracy.

Meanwhile, the majority of the public pemenak set tariffs that are pretty fantastic or expensive. ${ }^{5}$ In addition, the rates are absolute. In other words, the groom's family must fulfill the request set by the bride's family for the marriage to be carried out. Even in certain localities, many prospective brides' families still use certain symbols that reflect several items or money that the prospective groom's family must prepare if he wants to marry a noblewoman. The fantastic form of giving the pesuke is like a sum of money worth up to fifty million rupiahs added with a large area of rice fields, cattle or buffalo, and one sack of rice.

1 Tim Monografi Daerah NTB, Monografi Daerah Nusa Tenggara Barat (Mataram: Depdikbud, 1977).

${ }^{2}$ Interview with H. Lalu Darmawi on November 20, 2019.

${ }^{3}$ The provision of pesuke is almost similar to the rompak paga custom in the Minangkabau tribe, but the difference between the pesike giving with a certain amount is aimed at consensual families while the rompak paga custom of giving some customary money for the name of custom Salma and Burhanuddin, 'Study of 'Urf on Rompak Paga Tradition in Luhak Lima Puluh Kota of West Sumatra', Al Ihkam: Jurnal Hukum Dan Pranata Sosial, 12.2 (2017), p. 331.

${ }^{4}$ Data were obtained from observations at Marong Karang Tatah, November 23,2019

5 Interview with Ustadz Moh Tamim in Perbawe, Central Lombok on November 27, 2019. 
Determination of the value of pesuke by the bride and groom's family often leads to bargaining, which requires a relatively long time and usually even ends with a compulsion for the groom's family. Indeed, giving pesuke is worthy of the prospective groom's family has social status and can economically. However, suppose the prospective groom comes from a community with ordinary social status and the middle to lower economic level. In that case, pesuke rates that are too high often end up in abnormal marriages. Additionally, the worst thing that could happen is the wedding cancellation, although this case does not occur much. ${ }^{6}$

This fact shows that the Sasak people have commonly practiced this pesuke tradition even though it is not uncommon to cause various social problems. In addition, pesuke creates gaps in religious values, which can ease Muslims in carrying out marriages..

None of the sharia law requires that every man who will marry a woman submit a provision that the bride's family has set. Moreover, there is no rule forbidding the prospective bride to leave things that would be troublesome for the future husband she craved, including the provision of marriage. Although, in the marriage contract, the groom must give dowry to the bride. ${ }^{7}$ However, religion also suggests that the dowry's value must not be bothersome and burdensome for the prospective groom. ${ }^{8}$ As exemplified by the Prophet, if there is no gold, the dowry can be replaced with silver; if there is no silver, it can use copper, even iron is allowed. ${ }^{9}$ Wahbah Zuhaili also explained that the marriage also remained valid without it. ${ }^{10}$ The fatwa of Imam Syafii also strengthened that wedding can take place if it has completed the main pillars, namely offer (ijab) and

\footnotetext{
${ }^{6}$ Interview with Lalu Adnan at Marong Karang Tatah on November 23, 2019.

7 Abdul Azis Muhammad Azam, Fiqh Munakahat (Jakarta: Azzam, 2009), pp. 174-75.

${ }^{8}$ Slamet Abidin and Aminuddin, Fiqh Munakahat (Bandung: Pustaka Setia, 1999), p. 175.

${ }_{9}$ Kamal Mukhtar, Azas Azas Hukum Islam Tentang Perkawinan (Jakarta: Bulan Bintang, 1994), p. 82.

10 Wahbah Zuhaili, Al-Figh Al-Islāmi Wa Adillatuh (Damaskus: Dar al Fikr, 2010), p. 6578 Jilid IX.
} 
acceptance (qabul). ${ }^{11}$ Nevertheless, this tradition continues to be practiced by the Sasak Lombok community, especially in the locality of the aristocratic society, so people make pesuke a condition that must be present in the wedding ritual.

This study aims to elaborate and analyze the motivations behind setting high pesuke tariffs/prices, where the nobles of the Sasak tribe in Lombok making it as self-esteem and fixed price. This study also wants to examine how Islamic law views the practice of pesuke.

\section{Methods}

This study uses a social psychology approach, and collecting data is done through observation, interviews, and documentation. Meanwhile, the process of data validity uses Coopersmith's and Abraham Maslow's Self-esteem theory, Hogg D. Abraham's social identity theory, and social interaction theory to evaluate and analyze descriptively-analytic-inductive.

\section{Discussion and Result}

\section{Pesuke Tradition in the Sasak Noble Society}

The Sasak community in Lombok has social stratification consisting of three groups, namely, pemenak-perwangsa, and jajar karang. ${ }^{12}$ According to the statements of traditional leaders, religious leaders, and the community, the legality of the practice of pesuke is different for each group. Pesuke is a tradition that is already prevalent and has become the typical characteristic of the Sasak aristocratic community. However, over time this tradition has also developed among the jajar karang community.

H.L. Syafruddin explained that customary law agreed upon by specific communities, such as awig-awig regarding pesuke, ${ }^{13}$ belonged to the whole community and should not be bound by one

\footnotetext{
${ }^{11}$ Abdurrahman Al-Jaziri, Al-Figh 'Ala Al-Mazahib Al-Arba'Ah, 4th edn (Beirut: Dar alKutub al-Ilmiah, 2003), p. 16.

12 Social stratification in Sasak society categorizes humans into three groups, namely atu (aristocrats), pemenak-perwangsa, and jajar karang. Interview with Lalu Masykur on December 13, 2019.

13 The existence of awig-awig in this marriage is actually a form of accountability from the bride and groom who will hold the marriage, because
} 
particular social group or strata. ${ }^{14}$ Some areas that apply the pesuke tradition are Marong Karang Tatah, and Kamasan Mataram Environment in Mataram, Semayan, Prapen, and Perbawe villages in Central Lombok, West and East Sakra villages in East Lombok, and Kediri, Gerung and Kuripan villages in West Lombok. These areas become the sampling location of this research.

The determination of the amount of pesuke value also varies for each class of society. Society sets this value based on aji krame. ${ }^{15}$ Aji krame contains numerical symbols which are inherited from the kiyai and preachers. These symbols are the form of da'wah material used by the kiyai and preachers to spread Islam through cultural instruments, namely customs prevailing in the society. ${ }^{16}$

Aji krame has seven levels; the first level is called 5/400 (samas), ${ }^{17}$ which is a symbol for the Sasak people who have been able to pray five times a day or have practiced the five pillars of Islam. The second level is 7/400 (samas), symbolizing that humans besides knowing and believing in the pillars of faith are also aware of their obligations to study, especially religious knowledge. The third level is represented by the number 13 , which means that humans have run the pillars of thirteen, namely the pillars of prayer (shalat). The fourth level is symbolized by the number 17 , meaning seventeen rak'ahs of worship; that is, human beings are capable of and steadfastness (istiqamah) in performing prayers five times a day. The fifth level is symbolized by the number 33, which refers to humans who have been

according to Lombok custom the male side bears everything, including party financing and pesuke. Unlike the minang tribal marriage that marriage is a shared responsibility. Nofiardi, 'Marriage and Baganyi: Sociological Analysis of Culture in Dispute Resolution in Banuhampu District of Religious District', Al Ihkam: Jurnal Hukum Dan Pranata Sosial, 13.1 Juni (2018), p. 1.

${ }^{14}$ Interview with H.L. Syafruddin, the observer of the Sasak Lombok customs, December 7, 2019.

${ }^{15}$ Etymologically, aji krame comes from the Sasak language, divided into two terms, namely aji and krame. Aji means appreciation while krame is the result of a deliberation decision. In its terminological level, aji krame is a gift from a man family in the form of material to a woman's family according to the tradition or agreement of both parties. Interview with Lalu Najamudin on December 7, 2019.

${ }^{16}$ Compare to Zaki, 'Tradisi Islam Suku Sasak Di Bayan Lombok Barat, Studi Historis Tentang Islam Wetu Telu 1890-1965’ (UIN Sunan Kalijaga Yogyakarta), p. 10.

${ }^{17}$ Interview with Lalu Najamudin on December 7, 2019. 
able to carry out pillars 13 and understand and believe in the 20 attributes of Allah. This symbol is attached to those who already have a high enough degree of knowledge in fiqh, ushul, and Sufism. Finally, the sixth level is symbolized by the number 66 . This number is known as a "complete symbol" because humans have been able to carry out the pillars of Islam, pillars of faith, pillars 13, have known and believed like 20 for Allah, and are experts in prayer. The seventh level, symbolized by the number 100, is the most perfect and most complete symbol. This symbol means that humans have understood and believed 99 names of Allah (Asmaul Husna) plus one symbolizing obedience to the teachings of God.

Customary leaders agree that the krame aji contains positive values because it facilitates the marriage process in the Sasak community. Therefore, they hope and even oblige the public, especially the aristocracy, to practice the krame aji to determine pesuke value. Aji Krame also indirectly informs that these symbols represent the strata or groups of the community. The symbol number 100 is a tribute to the nobility. The number 66 (enam dase enem) symbolizes the price for perwangsa (pemenak). The number 33 (telung dase telu) symbolizes appreciation for the jajar karang community. While the society which consists of the laborers, slaves are valued by the symbol 5/400 (samas).

Customs in the Sasak community are categorized into three, namely adat game, adat wiragama, and adat tapsile ${ }^{18}$. This pesuke tradition is included in adat tapsile because it is related to manners between fellow humans (muamalah). Therefore, determining pesuke by aji krame in the marriage process must be done. The value of pesuke who does not follow the rules of aji krame is a violation of the agreed custom. ${ }^{19}$

Based on aji krame there are three types of gifts from the prospective groom's family to the prospective bride's family. First, the

18 Adat game is human procedures in establishing good relations with the creator. Adat wirgama is a way for humans to interact with the natural surroundings and love other creatures that live around them. While adat tapsile is procedures for establishing social relationships with others. In the language of religion it is often referred to as hablum minallah, hablun min al-kainaat, hablum min An-nas. Interview with Lalu Syafrudin on 10 December 2019.

${ }^{19}$ Interview with H. Lalu Darwami, 10 December 2019. 
giving of the groom's family in the form of material based on sincerity. ${ }^{20}$ This pesuke can be a specific item in the amount adjusted to the will and ability of the prospective groom's family. ${ }^{21}$ Second, it is also called trasne dane, which gives the prospective groom's family to the bride-to-be based on excessive love. Third, it is called gantiran. ${ }^{22}$ H.L. Syafruddin explained that gantiran consists of two words, namely the word ganti and ran. When the two words are together, it becomes a term with meaning in terms of terminology, replacing the cost incurred during a begawe (party). ${ }^{23}$

The practice of pesuke is already attached to the Sasak aristocratic society. Those nobles are also very committed to using symbols that symbolize the number and types of requests of the bride and groom's family. Some regions still apply this old concept or tradition, such as in the Semayan area, the prospective bride brings two coconuts and a handful of rice to the prospective groom's family. This symbol implies that the groom must give a pair of buffalo and a sack of rice to the prospective bride's family. Thus, the amount of pesuke is highly dependent on the symbols carried by the future bride. In addition, some people hand over the gantiran or pesuke in the form of a plot of paddy land. The groom will adjust the rice fields given to the bride's family according to the custom prevailing in the bride's residence.

In principle, customs must remain in the constellation of religion. Therefore, The ancestors have adjusted the Sasak cultural literature traditions to religious teachings, including customary requests for pisuke, gantiran, and aji krame. ${ }^{24}$ According to the essence of traditional Sasak marriage, it is not allowed to be burdensome and also not to be too light to remain in the corridor of the Sasak

${ }^{20}$ Interview with Lalu Muhammad Zakaria Mataram. the 18th of 2019.

${ }^{21}$ Interview with H.L. Syafruddin, December 202019.

22 This gantiran tradition is considered as compensation between villages. For example, a man who lived in village A applied for a woman from village B with the conditions agreed upon by the customs of the two villages. If village A pays pesuke with a pair of buffalo and $100 \mathrm{~kg}$ of rice, then Village B must pay the same amount if its community members apply for women from Kampung A, according to the agreement between the two villages.

${ }^{23}$ Interview with Lalu Safiudin Mataram, 20 December 2019.

${ }^{24}$ Interview with Lalu Masykur, December 23, 2019. 
traditional principle, which is patut, patuh, pacu, solah, onyak, saleh, soloh. $^{25}$ This principle is in line with the statement of Lalu Syafrudin, that by practicing awig-awig that the previous traditional leaders have determined the pesuke will not impose on the groom's family. ${ }^{26}$ For example, for nobles with the symbol number 100, the pisuke must is a cow and a sack of rice.

However, today's phenomenon is that many Sasak people are burdensome to each other by establishing the excessive value of pesantiran or pesuke ranging from millions to tens of millions, and some even use cows buffaloes, rice fields, and so on. They call this gift with the terms gantiran tinduk and gantiran nganjeng. ${ }^{27}$ This phenomenon shows that customary practices have changed from the customs that they should-determination of the value of Pisuke, which actually must be by the provisions of aji krame.

A change in social behavior triggered the adat shift due to Law No. 5 of 74 concerning village government regulations and Law No. 5 of 79 concerning regional governance. The issuance of the two constitutions because of kuningisasi, namely the interests of the Golongan Karya party at that time. The village head who lacked

25 The customary principle referred to in the pesuke tradition in the Sasak community is the provision of assistance by the groom's family to the bride's family in the form of money or goods in accordance with the agreed awig-awig. This assistance is given in the hope that a peaceful atmosphere will be established between the two parties, especially between the bride and groom in order to foster a household based on keistiqamahan (diligently) carrying out their duties and obligations as husband and wife, so that a good, safe, harmonious, prosperous, sakinah, mawaddah, and rahmah family could be formed, Interview with H. L. Syafruddin, January 20, 2019.

${ }^{26}$ Pesuke tradition is expensive today because the practice of marriage carried out by the people of Lombok is much contrary to the actual Islamic law. Whereas marriage is with all its conditions such as initial inection is a human relationship with others who want a horizontal relationship with peaceful coexistence, harmony and away from violations that can harm themselves and others. Suhaimi, 'Praktik Khitbah Di Madura Perspektif Hukum Islam Dan Hukum Adat', Al Ihkam: Jurnal Hukum Dan Pranata Sosial, IX.2 (2014), p. 306.

${ }^{27}$ Gantiran tinduk is the pesuke of the prospective groom to the bride's family in the form of several cashed cows. While gantiran nganjeng is the pesuke of the prospective groom to the bride's family in the form of several cows, which both parties have agreed on numbers. Interview with Lalu Masykur Lalu Syafruddin, December 18, 2019. 
understanding of adat issued a regulation to determine pesuke value that was not by the aji krame as determined by previous traditional leaders. This phenomenon occurs because many Sasak people have abandoned local wisdom. This situation gave birth to freedom for community leaders in the village to decide customary rules based on a community agreement. ${ }^{28}$

In addition, at present, the determination of pesuke in the Sasak community is still uncertain. ${ }^{29}$ The decision of the number of pesuke (suluh) in the community, sometimes it can be expensive sometimes it is cheap. It depends on the bargaining between the two families, even though the people who hold the marriage are not nobility. According to TGH Abdullah Hakam, the pesuke value requested by the bride's family is between 5 million to 20 million, depending on the bargaining results between the two families. Even in the Tiwu Galih area, the pesuke value could reach 30 million. Marriage registration officers in the Semayan area have also found that the number of pesuke in the area reached 50 million. ${ }^{30}$ However, people should no longer view this pesuke tradition as a request but a mandatory gift worthy of being given by the prospective groom to the bride. ${ }^{31}$

In addition, the people of Lombok also believe that every habit that contains goodness can be the basis for legal products that can develop in society. Thus, the Sasak nobles continue to maintain this tradition because they want to uphold the values of goodness contained in it. ${ }^{32}$ Furthermore, Abdul Wahab Khallaf stated that all elements of society could accept a custom if the custom brings benefit. ${ }^{33}$ Therefore, Pesuke becomes a legitimate activity because it produces an agreement from both parties who will get married. The nobles have carried out this tradition for generations, and so far, no upheaval. Therefore, the pesuke practice is a practical matter and does

\footnotetext{
${ }^{28}$ Interview with Lalu Syafruddin, December 18, 2019.

${ }^{29}$ Interview with TGH Abdullah Hakam on 31 December 2019.

${ }^{30}$ Interview with TGH Abdullah Hakam on 31 December 2019.

${ }^{31}$ Interview with Lalu Azmil Kafrawi December 31, 2019.

${ }^{32}$ Rasyid Hasan Khalil, Tarikh Tasyri' (Jakarta: Amzah, 2009), p. 169.

33 Abdul Wahab Khallaf, Ilmu Ushul Figh (Kaidah Hukum Islam) (Jakarta: Pustaka Amani), pp. 118-19.
} 
not conflict with the legality of the law contained in the Qur'an and Sunnah. In his usul fiqh, Abu Zahrah explained that people must preserve an 'urf or a good habit. ${ }^{34}$ Abdullah bin Mas'ud also revealed;

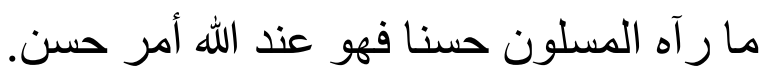

Meaning: "Whatever is considered reasonable by the Muslims, then that matter is good according to Allah." 35

Therefore, the community uses the above expression of the ulama as the basis for maintaining pesuke. This basis also constructs people's thinking that leaving pesuke means lowering the self-esteem of the community concerned. Therefore, this pesuke becomes a fixed price that must be continuously fought for so that the dignity of the nobility remains respected.

\section{Pesuke as a Defense of Self-Esteem and Fixed Price in Noble Society}

There are still many Sasak aristocratic people who practice the old customs they received from their ancestors. For example, the business of determining pesuke value is different from other groups of people. TGH Fahrurrazi, head of the Nurul Yakin Praya boarding school, also conveyed this statement, who stated that the Sasak aristocratic community was different from other communities; they still maintained the local custom by setting pesuke rates high enough. Pesuke that is requested is usually valuables or money, depending on the traditions they agree on in each hamlet and village. ${ }^{36}$

The following factors behind the community maintaining this tradition; First, the married woman will still have dignity. ${ }^{37}$ This reason is strong to justify preserving the practice of pesuke in Sasak society, especially among the nobility, especially when considering

\footnotetext{
${ }^{34}$ Muhammad Abu Zahrah, Ushul Figh (Jakarta: Pustaka Firdaus, 2003), p. 116. 35 This ini In line with Nouruzzaman's opinion, quoting the views of the Maliki and Hanafi schools that urf is a source of Islamic law outside the texts scope Nouruzzaman Shiddiqi, Fiqih Indonesia, Penggagas Dan Gagasannya (Yogyakarta: Pustaka Pelajar, 1997), pp. 122-23.

${ }^{36}$ Interview with TGH Fahrurrazi on 28 December 2019.

37 Drs. H. Then Makmur, 'The Head of Religious Affairs (KUA) of Praya Subdistrict', 2019, Direct Interview on November 27, 2019.
} 
that noblewomen are descendants of the blue blood of kings who have high social and economic status in the community. Thus, maintaining this pesuke meant an effort to preserve the dignity of the nobles.

TGH Fahrurrazi also explained that pesuke as suluh/islah, which means peace or improvement. Therefore, the money given by the prospective groom to the prospective bride's family to carry out the marriage contract is called uang suluh (peace money). 38 Therefore pesuke or suluh is a custom performed by Sasak people in marriages where the family of a man gives money or goods by the request and agreement between the two parties to improve conditions while creating peace between the two parties. ${ }^{39}$ Second, pesuke is adat, because adat is part of religious rules, so it is not wrong if implemented. This view becomes legal, aside from the fact that this view still prevails in society and according to the ushul fiqh method, which explains that: " العادة محكمات " (adat is the law).

Meanwhile, the demand for pesuke with a high enough price manifests deviations from the rules or awig-awig agreed upon by the community, namely regarding the elopement tradition, which is considered a despicable act a harmful activity. A man who does elope will be given an adat sanction in the form of an expensive ransom payment because this action can damage family relations. ${ }^{41} \mathrm{~A}$ marriage registration officer of the Semayan village, Ustazd L. Tamim, stated that the pesuke request was also based on the dislike of one of the bride and groom's family parties for the marriage. ${ }^{42}$

In addition, another factor that causes pesuke to be expensive is the existence of a policy to equalize pesuke values so that it does not occur "biased" in social stratification. In addition, if adat has set 30 million in a village, then the value of pesuke remains 30 million onwards, regardless of whether they are aristocrats or jajar karang.

${ }^{38}$ Interview with TGH Fahrurrazi on December 28, 2019.

${ }^{39}$ Interview with TGH Izzudin Habib on December 31, 2019.

${ }^{40}$ Interview with TGH Izzudin Habib on July 14, 2007.

${ }^{41}$ H. Syawal, 'The Marriage Registration Officer in the Prapen Sub-District', 2019 Direct Interview on December 15, 2019,

42 Direct Interview on December 31, 2019, Ustadz L. Tamim, 'Marriage Registrar', 2019. 
Marriage between aristocrats with jajar karang can also be the cause of the high pesuke. In this context, pesuke is a means to reconcile a family atmosphere so that the relationship between the two families from different strata can remain safe. ${ }^{43}$ Since, if the groom is given the convenience, namely by asking for a cheap pesuke, the groom will not be charged certain costs, someday the man may not respect his daughter and treat her like a reasonable and useless wife. ${ }^{44}$ Therefore, the Sasak aristocratic people usually setpesuke in the form of a considerable amount of money, which reached tens of millions of rupiah. Ustazd L Tamim also informed that there was a family of the bride who set pesuke went 50 million, for reasons of prestige.

The lack of educational equality between the bride and groom is also the cause of the high pesuke tariff, especially if the room is lower than the bride's. ${ }^{45}$ As stated by TGH Fahrurrazi, that taking a dowry is required to be expensive so as not to be demeaned. ${ }^{46}$ Coopersmith also explains related to this view that one's abilities can be the basis for the emergence of self-esteem. ${ }^{47}$

Whereas in Islam, the mahr (dowry) must be simplified, meaning that it is affordable by the community. ${ }^{48}$ TGH Mashun strengthen his argument with a hadith (بركهن أيسرهن مهور) ( the marriage obtained by lightening the amount of dowry". The same opinion has also been conveyed by the Marriage Registration Officers at the Office of Religious Affairs. They served in all areas of East Lombok, Central Lombok, West Lombok, and Mataram.

However, all of the above factors become a powerful motivation and can shape the awareness of the Lombok people to

\footnotetext{
${ }^{43}$ Interview with TGH Izzudin Habib on December 31, 2019.

${ }^{44}$ Interview with TGH Izzudin Habib on December 31, 2019.

${ }^{45}$ Interview with Semayan sub-district marriage registration officer Ustazd L. Tamim on December 31, 2019.

${ }^{46}$ Interview with TGH. Fahrurrrazi on December 28, 2019.

${ }^{47}$ Stanley Coopersmith, The Antecendents of Self Esteem (San Fransisco: Freeman Press, 1967).

${ }^{48}$ Interview with TGH. Fahrurrrazi on December 28, 2019.
} 
maintain their self-esteem. Coopersmith explains that strength could be a factor that forms the self-esteem of society. ${ }^{49}$

\section{Analysis of the Aspects of Self-Esteem and Fixed Price in Determining the Value of Pesuke.}

\section{Self-esteem as the Basis for Determination Pesuke in the Sasak Nobility Society}

Humans are born as social beings; this fact causes humans can not usually live without the presence of others. ${ }^{50}$ Amin Abdullah explained that plural human affairs could cause various conflicts. This condition will encourage humans to make accommodations to realize wise social attitudes among one another. ${ }^{51}$

Marriage is one way that can accommodate social action in society. Since marriage can bring together different sexes, ethnicities, races, groups, and even religions through dynamic interactions between individuals or groups, as revealed by Elly M. Setiadi. ${ }^{52}$ Thus, the practice of marriage has touched aspects of the high-class social paradigm. ${ }^{53}$ Marriage not only brings together or brings one group closer to another group but also unites all the differences that exist in the form of an element that complements society, namely the family. Mainly, suppose marriage is carried out by strict customs, such as those carried out by the Sasak aristocratic community. In that case, social interaction must be continuously carried out until the wedding is implemented.

Midang tradition, the introductory stage between the prospective groom and bride, is the initial social interaction between

49 Aditomo and Retnowati, Perfeksionisme, Harga Diri, Dan Kecenderungan Depresi Pada Remaja Akhir (Yogyakarta: Fakultas Psikologi Universitas Gadjah Mada, 2004).

50 Asrul Muslim, 'Interaksi Sosial Dalam Masyarakat Multietnis', Jurnal Diskursus Islam, 1.3 (2013), p. 485.

51 Amin Abdullah, Dinamika Islam Kultural; Pemetaan Atas Wacana Keilsaman Kontemporer (Bandung: Mizan, 2000), pp. 68-69.

52 Elly M Setiadi \& Usman Kolip, Pengantar Sosiologi Pemahaman Fakta Dan Gejala Permasalahan Sosial: Teori, Aplikasi, Dan Pemecahannya (Jakarta: Kencana, 2011), p. 63.

53 Stephen Cotgrove, The Science of Sociology: An Introduction to Sociology (London: Gerge Allan \& Unwin, 1982). 
the two parties. At this stage, the man will attract the heart of the woman he adores with various sweet talks so that he is accepted as her life partner. Furthermore, the acceptance or approval of a bride for the marriage is also a series of social interactions that people cannot avoid. Therefore, there will be various negotiations and social contacts $^{54}$ in realizing marriage. Although, social interactions are also carried out not infrequently, causing disintegration, conflict, and social rift. ${ }^{55}$ For example, in the process of determining pesuke value. This process must get agreement from both parties, both in the manifest (zahir) and the hidden (batin).

Marriage carried out according to customs is a form of community care in preserving local wisdom. This tradition has been created and agreed upon as an activity that can provide significant benefits (maslahah) for the community, especially for those who practice it. Thus, it is natural that this tradition continues to be maintained and preserved. Everyone is forbidden to leave it. Even in some places, it becomes a non-negotiable rule, even though some community members are jajar karang who do not have an obligation to practice it. ${ }^{56}$ For example, the practice of determining pesuke value in villages or hamlets where aristocrats inhabit the majority of the population. All forms of awig-awig or existing customs should not be abandoned by all community members, even though some of the inhabitants are jajar karang.

Pesuke tradition has become one of the Sasak community identities that people should respect. Previous societies sacrificed considerable expense, time, and energy to create it, so it was natural to appreciate people who used it. If referring to the concept of self-

54 This has become an internal community paradigm because it is done through systematic social interaction Kinlockh Graham C., Ideology and the Social Science (Greenwoon Press, 1981). See also Zainuddin Maliki, Narasi Agung Tiga Teori Sosial Hegemonik (Surabaya: LPAM, 2004), p. 19.

${ }^{55}$ In many ways George Foster tries to suggest that the mechanism of social value still applies through a sense of limitations on Resources. Peasant Sciety and the Image of Limitied Good in Jack M. Potter, May N. Diaz and George N. Foster (eds) Peasant Society: A Reader (Boston: Little Brownan Company).

56 Muhammad Salim Mazkur, Madkhal Figh Al-Islam (Kairo: Dar alQaumiyyah, 1964), p. 120. See also Yusuf Qardawi, Awami Al-Sa'ah Wa Al-Murunah Fi Al-Syari ah Al-Islamiyah Bayna Al-Inzibath Wa Al-Infirat (Kairo: Dar al-Tauzi wa alNasyr al-Islamiyyah, 1994), p. 18. 
esteem Nathaniel Branden, the struggle of the Sasak people in facing challenges and threats that can depose the pesuke tradition is believed to be a noble deed. Therefore, the community must maintain this tradition so that it cannot be torn apart by anyone. ${ }^{57}$

Moreover, the struggle that deserves high respect is the struggle of the predecessors of the Sasak people when giving a solid understanding for the community that the pesuke tradition is should not be crushed by the times. This pesuke tradition has a very high philosophical meaning because pesuke can create a sense of ridha (contentment with God), pleasure, peace, and security in family life. The goal is to reconcile the two parties that will carry out a marriage can be realized. These traditional values should be fought to be made as necessary by the people, especially the aristocratic community thick with tradition and customs. Nathaniel Branden states that people's confidence to get the right to happiness and feelings of worth to assert the needs and desires that they can enjoy because of their hard work. 58

The functions and benefits of the pesuke tradition must be fully understood by the Sasak people so that others can appreciate them. As Abraham Maslow's view of esteem theory, the Sasak people, especially those of nobility, must respect themselves by maintaining their tradition as an activity that has a high value in front of others so that the dignity of the Sasak nobility is maintained. According to Maslow, if the community has maintained their self-esteem, an honor will automatically be obtained. ${ }^{59}$ Therefore, various forms of struggle of the Sasak people in maintaining and making people understand the benefit of the pesuke tradition have been considered a success or achievement worthy of appreciation. So, it is natural that the selfesteem of the Sasak people, especially the nobles, can still be maintained. ${ }^{60}$

\footnotetext{
57 Nathaniel Branden, The Power of Self-Esteem (Florida: Health Communications, 1992), p. 97.

${ }^{58}$ Nathaniel Branden, 97.

59 Abraham Maslow, Motivation and Personality (New York: Harper And Row Publishers, 1975).

${ }^{60}$ F.A Rohmah, 'Pengaruh Pelatihan Harga Diri Terhadap Penyesuaian Diri Pada Remaja', Humanitas (Jurnal Pskologi Indonesia), 1.1, pp. 53-56.
} 
Thus, the determination of pesuke tariffs that "seem" to burden the prospective groom's family is not worth the sacrifice that has been done in maintaining pesuke traditions in the community. Rusli Rutan states that everyone deserves to be valuable and beneficial for all efforts done, no matter what has been, is, and will happen. ${ }^{61}$ Likewise, in the pesuke tradition, Sasak aristocratic society cannot blame if it persists in setting a fantastic pesuke price even though it will be burdensome for the groom's family.

If referring to illat (a trait that allegedly contained legal purposes) of the implementation of pesuke, this pesuke is valid at least normatively formal legal and can be tolerated in Islamic law. ${ }^{62}$ The fundamental reason for implementing the pesuke is that it can realize the value of the maqashid syariah (goals or purpose of Sharia), which is to reconcile both parties so that they can sail the ark of their household safely, comfortably, and happily. ${ }^{63}$ Thus, the gathering (silaturrahmi) between the bride and groom's family also can occur continuously so that an intact family is formed which is framed with happiness. Meanwhile, the consequences or risks arising from the enactment of this pesuke cannot be used as illat to undermine the traditions inherent in the life of the Sasak aristocratic society. Thus, the man who wants to marry a noblewoman must be prepared with an expensive pesuke and ready to face all the consequences that would occur.

The pesuke tradition that is expected to create peace between the bride and groom's family can be felt by both prospective bride and groom that their marriage is based on kindness, happiness, serenity, willingness, and comfort. Thus, the tradition is also expected to be a prayer for the bride and groom to become a sakinah, mawaddah, rahmah, safe, happy family in the world to the hereafter. ${ }^{64}$ Therefore,

${ }^{61}$ Rusli Rutan, Self Esteem: Landasan Keperibadian (Jakarta: Proyek Peningkatan Mutu Organisasi dan Tenaga Keolahragaan Dirjen Olahraga Depdiknas), p. 86.

${ }^{62}$ Nadiyah Syarif al-Umari, Ijtihad Fi Al-Islam (Give: Muassasat al-Risalah, 1981), p. 255. See also Musthafa Said al-Khin, Al-Kafi Wa Al-Wafi Fi Ushul Al-Figh AlIslami (Beirut: Muassasat al-Risalah), p. 181.

63 Muhammad Khalid Mas`ud, Islamic Legal Philosophy (Islamabad: Islamic Research Institut, 1977), p. 232.

${ }^{64}$ It is obtained by both the bride and groom and their families. It can be categorized as general self-esteem, which confirms that pesuke is like capital to 
the ancestors' struggle in producing something good to be passed on to their successors is a very noble act and needs to be emulated from one generation to the next.

Based on social identity theory, people will continue to struggle hard to maintain the positive value of their social identity. ${ }^{65}$ Therefore, all efforts made by the traditional leaders to preserve the tradition of this pesuke are good things. ${ }^{66}$ The form of the struggle of traditional leaders in making people understand and aware of the practices that they must maintain can prove that the identity of the nobility respects the positive values of the customs of their ancestors. This attitude is not yet shared by other groups such as the priyai, jajar karang, and others. ${ }^{67}$ Thus, this attitude should be understood and embraced by all social strata in society. The pesuke tariff rules that apply to the Sasak aristocracy also should apply to jajar karang. Thus, the jajar karang community and the nobility must get the same treatment and have the same rights and responsibilities in developing and preserving the customs developed in specific neighborhoods, even though they are a minority community. ${ }^{68}$ According to Hogg, et al., this effort is also one method that can be applied in building and respecting the identity of other people or groups. Furthermore, Hogg also stated that a plural community could create a positive identity if they respect each other's identity. This theory emphasizes that a group will have a positive selfidentity if they can appreciate the uniqueness of other groups. ${ }^{69}$ In other words, the self-esteem of the Sasak aristocratic community will depend significantly on the extent to which they can maintain their

maintain self-esteem because it is obtained from the experience and history of the Sasak tribe. See Marjohan, 'An Investigation of Factors That Influences Decision and Their Relationship to Self-Esteem and Locus of Control Among Minangkabau Students' (University of Tasmania Australia, 1977).

65 Muhammad Johan N Huda, ‘Dinamika Pencapaian Identias Sosial Postif Atas Keistimewaaan Yogyakarta', Jurnal Pskologi Integratif, 2.1 (2014), pp. 30-41.

${ }^{66}$ J. C. Giles Turner, Howard, Intergroup Behavior (Oxford: Blackwell, 1981).

67 Michael A Hogg \& D. Abrams, 'Social Motivation, Self Esteem Social Identity', in Social Identity Theory: Constructive Dan Critical Advance, ed. by D. Abrams \& M.A. Hogg (New York: Havaerster Wheatsheaf, 1990), pp. 28-47.

${ }^{68}$ Klandermans, The Social Psychology of Preotes (Oxford: Blackwell, 1977).

69 Alexander Haslam, Psychology in Organization (The Social Identity Approach) (New Delhi: Sage Publication, 2001). 
identity and respect the uniqueness of different groups, such as the jajar karang. McDonal's Self Esteem theory in Cicilia reinforces this statement by explaining that the existence of a person or community in maintaining identity is an integral part of realizing self-esteem because social identity is one of the tools to get appreciation from other groups. $^{70}$

The phenomenon that occurs today is that many people do not require pesuke in their marriage processions. Some people set pesuke but not made as a priority. Usually, the pesuke tradition must be a priority because it is one of the most crucial discussion topics when the two families interact. ${ }^{71}$ Marriage will have value and dignity in the community when it is normally carried out, where interaction creates comfort, security, peace, happiness, and willingness between the two parties. ${ }^{72}$ Moreover, the blessing will accompany the bride and groom undergoing the household ark because it begins with good social interaction between the two families. $^{73}$

Social contact that continues with intense communication between the two parties is a form of social interaction that cannot be left behind in the marriage tradition. ${ }^{74}$ The process of discussing the implementation of the wedding to the offer of pesuke made by the prospective groom's family is also an effort to maintain self-identity so that it remains valuable in the community. ${ }^{75}$ Accommodation needs to be done to make adjustments between the two families. The

70 Y. Cicilia Praswati, ‘Pertikaian Kelompok Etnik Di Kalamantan Barat: Tinjauan Berdasarkan Teori Identitas Sosial', Jurnal Psikologi Sosial, 2003, p. 77.

71 The point is as a basis for bringing the two families closer, Knapp L., Interpersonal Communication and Human Relationship (Newton MA: Allyn And Bacon, 1984).

72 D.O, Sears, L.A. Pelau \& Taylor, Social Psychology (Englewood Cliffs NJ, Prentice Hall, Inc, 1991), p. 91.

73 Muhammad Dja far, Etika Bisnis Islami Dalam Tataran Teoritis Dan Praktis (Malang: UIN Malang Press, 2008), p. 63.

${ }^{74}$ M. Bahauddin al-Qibbani, Al-Faqru Wa Al-Ghina Fi Al-Qur`an Al-Karim (Kairo: Muassasah Dar al-Sya`b), p. 190.

75 Maintain self-esteem by maintaining self-identity, namely preserving the pesuke tradition as a social attribute inherent in the Sasak aristocratic society and cannot be influenced/changed, R.B. Burns, The Self Concept Theory, Measurement, Development and Behaviour (London: Longman Group, 1979). 
groom's family must understand the condition of the bride's family, must not bargain the tariff of pesuke is too cheap because it is feared that it will lower the bride's family's self-esteem. Vice versa, the bride's family should not set the price of the pesuke as they please without understanding the condition of the groom's family. ${ }^{76}$ This means that the bride's family is not wrong if they ask for a high pesuke, as long as the groom's family agrees. The essence of this interaction is to understand each other between the two parties by minimizing all the bad possibilities that can occur, such as the impression that marriage is not blessed, various family conflicts, and a broken home. All these interactions are carried out solely to keep the family's dignity remains safe, peaceful, and prosperous in the world until the hereafter, by the purpose of the pesuke tradition so that the preservation of self-esteem remains a priority. ${ }^{77}$ Thus, social interaction can be a means of resolving internal conflicts that may occur between the two parties at the time of determining the pesuke value. This conflict can be resolved through correction, compromise, mediation, arbitration, adjudication, stalemate, tolerance, and conciliation. ${ }^{78}$

\section{Fixed Price in Determination of Pesuke in the Sasak Nobility Society}

The motivation to maintain the pesuke tradition is not limited to self-esteem and self-identity. However, this tradition has become a "fixed price" that no one must deny. Thus, all efforts made to preserve and maintain it are part of preserving the identity of the Sasak aristocratic community so that it is not underestimated by other groups or members of the community. ${ }^{79}$

\footnotetext{
77 M.H. Guindon, Self Esteem Across The Lifespan (New York: Francis Group LCC, 2010), p. 11.

${ }^{78}$ Jabal Tarik Ibrahim, Sosiologi Pedesaan (Malang: Universitas Muhammadiyah Malang, 2003), p. 22.

${ }^{79}$ M. Rosenberg, Society and The Adolescent Self-Image (Pincestin NJ: Princeton University Press, 1965), p. This means that the self-esteem shown by the Sasak community is in the form of positive values, as initiated by Rosenberg, See.
} 
In general, the existence of pesuke in the internal Sasak community is seen as giving the prospective groom's family to the prospective bride's family that is "fixed price". ${ }^{80}$ Therefore, all Sasak people must carry out this pesuke tradition in their marriage procession, regardless of social stratification.

Moreover, if the marriage is not carried out typically (by adat), then the process of determining pesuke may also not be carried out usually. This means that the specified pesuke value could be cheaper and more expensive than the value. Myers states that a person or group with high self-esteem, such as a noble community, may experience failure or disappointment, which makes his self-esteem decline. ${ }^{81}$ In other words, if a nobleman does not carry out this tradition, then his self-esteem may be lowered by the community. It is the consequence that will be received by someone who lives in an environment that is bound by solid customs.

In essence, pesuke has become a fixed price in Sasak marriages because the Sasak people, especially the nobility, have realized that the Sasak tribe also has a dignity that must be maintained, even though the prospective bride will be at stake. That means the marriage will be held or foiled depending on the ability of the prospective groom's family to pay for the pesuke. Marriage can continue without pesuke. ${ }^{82}$ However, the absence of pesuke will raise public opinion that the wedding did not get the family's blessing. The community also believes that various threats and disasters will occur in the household. ${ }^{83}$

That is why pesuke is used as a fixed price by the noble Sasak people. The bride's family will not even hesitate to dispose of (not regard) his daughter customarily if she violates the rules or traditions in the Sasak marriage. This practice is commonly called "buang telur"

${ }^{80}$ Steven Fein \& S.J. Spencer, 'Prejudice as Self Image Maintenance: Affirming The Self-Through Derogating Others', Journal of Personal and Social Psychology, 73 (1997), pp. 31-34.

${ }^{81}$ D. Myers, Social Psychology (New York: Mc Graw-Hill, 2005), p. 75.

82 M. Nur Yasin, 'Kontekstualisasi Doktrin Tradisional Di Tengah Modernisasi Hukum Nasional: Studi Tentang Kawin Lari (Merari`) Di Pulau Lombok', Jurnal Istinbath, IV.1 (2006), pp. 73-75.

83 Wilis Srusayekti dan David A. Setiady, 'Harga Diri Terancam Dan Perliaku Menghindar', Jurnal Pskologi, 42.2 (2015), pp. 141-56. 
(egg disposal). ${ }^{84}$ This means that the family will not regret disposing of/ not regarding their daughter as part of their flesh and blood (descendant). ${ }^{85}$ As a result of the violation, the dignity of his family's nobility was tarnished. However, the situation can still be restored if the prospective groom makes pesuke payments as a ransom for the woman he is going to marry, and his wedding is also celebrated in tradition or custom. ${ }^{86}$

Therefore, this pesuke tradition becomes a fixed price if the two brides are from the aristocracy and marry with an unjustified system, both socially and religiously. For example, they get married using a melaik marriage system. Married using this marriage system is very risky in causing dire consequences for both families. ${ }^{87} \mathrm{~A}$ marriage supposed to bring pleasure, peace, family atmosphere, and blessing turns into a marriage colored with hatred, anger, and resentment. In addition, if the bride's family finds out that the groom's family has complained about the pesuke being too expensive. Then automatically, the pesuke becomes the fixed price required by a woman's family. If the bride's family does not ask the pesuke, society will underestimate the dignity of the bride and her family. Mc. Donald said that basically what Sasak people do is a technical / way to maintain their ethnic self-esteem. ${ }^{88}$

On the one hand, if the prospective groom's family does not fulfill the pesuke by the request of the woman's family, one of the consequences that the future groom and his family must receive is the difficulty of getting a marriage guardian. Suppose the marriage continues to be carried out unilaterally by bringing in a guardian of the judge and secretly held. In that case, the bride's family will not allow the bride and groom to carry out the nyongkolan, bejango,

\footnotetext{
${ }^{84}$ Neuwenhuyzen called it the Sasak custom which was actually practiced for good and benefit. Tim Departemen Pendidikan dan Kebudayaan, Adat dan Upacara Perkawinan Daerah Nusa Tenggara Barat (Jakarta: Depdikbud, 1995), 11.

85 John Bartholomew stated that this custom as a result of the acculturation of Balinese and Sasak culture, in the merari 'custom, John Ryan Bartholomew, Alif Lam Mim: Kearifan Masyarakat Sasak (Yogyakarta: Tiara Wacana, 2001), p. 203.

${ }^{86}$ Wilis Srusayekti dan David A. Setiady, p. 143.

${ }^{87}$ Fath Zakaria, Mozaik Budaya Orang Mataram (Mataram: Yayasan Sumurmas Al-Hamidy, 1998), p. 10.

${ }^{88}$ Y. Cicilia Praswati, p. 77.
} 
and silaturrahim tradition. ${ }^{89}$ That's how the Sasak people, especially the nobility, maintain their self-esteem as a positive identity so that this pesuke tradition is known by the public as a fixed price. ${ }^{90}$

Pesuke as a fixed price is also very visible in meruput marriage system. In this system, the two families of the bride and groom do not approve of the marriage contract. This disagreement occurs if the bride and groom come from different social strata. Moreover, if the prospective bride is of royal descent, the future groom is a jajar karang society. ${ }^{91}$ In this case, the bride will be disposed of traditionally by her family if the marriage continues. ${ }^{92}$ For the conflict between the bride and groom's families to end and peace be achieved, the male family must pay the pesuke tariff that is more expensive than the usual rate.

\section{Conclusion}

The pesuke tradition is one of the traditions practiced by the Sasak people in marriage rituals. This tradition is in the form of handing over goods or money from the prospective groom's family to the bride's family as a guarantee for the continuity of the marriage contract and creating a sakinah, mawaddah, and rahmah family. Thus, the community determines the value of pesuke, referring to the awig-awig prevailing in the society. They also remain steadfast in preserving pesuke because this tradition has a good purpose: to maintain the dignity of women and their families.

On the one hand, the high pesuke value can have a positive impact, such as the impression that the relationship between the bride and groom's families is happily, peacefully, and respectfully established. However, on the other hand, a high pesuke value can also negatively impact conflict and disagreement. Interestingly, today's phenomenon, the value of pesuke among aristocrats and jajar karang

89 Muhamamd Harfin Zuhdi, Bias Gender Stratifikasi Perempuan Bangsawan Sasak Dalam Perkwainan Masyarakat Lombok Nusa Tenggara Barat (Jakarta, 2010).

${ }^{90}$ Nathaniel Branden.

${ }^{91}$ Bustami Saladin, 'Tradisi Merari' Suku Sasak Di Lombok Dalam Perspektif Hukum Islam', Al Ihkam: Jurnal Hukum Dan Pranata Sosial, 8.1 (2013), p. 22.

92 Gde Suparman, Titi Tata Adat Perkawinan Sasak, Kepembayunan Lan Candrasengkala (Mataram: Lembaga Pembukuan dan Penyebaran Adat Sasak Mataram Lombok, 1988). 
is often equalized. Therefore, if this phenomenon is not handled wisely and earnestly, it can threaten the peace of the village.

However, pesuke tradition is seen as a manifestation of the self-esteem of Sasak community that must be maintained and preserved. Therefore, the expensive pesuke is applied in society for the dignity of the Sasak community to be respected. The grace of the community will be more valuable and prestigious with the practice of this tradition.

\section{Bibliography}

Abdul Azis Muhammad Azam, Figh Munakahat (Jakarta: Azzam, 2009)

Abdul Wahab Khallaf, Ilmu Ushul Figh (Kaidah Hukum Islam) (Jakarta: Pustaka Amani)

Abraham Maslow, Motivation and Personality (New York: Harper And Row Publishers, 1975)

Aditomo and Retnowati, Perfeksionisme, Harga Diri, Dan Kecenderungan Depresi Pada Remaja Akhir (Yogyakarta: Fakultas Psikologi Universitas Gadjah Mada, 2004)

Al-Jaziri, Abdurrahman, Al-Figh 'Ala Al-Mazahib Al-Arba'Ah, 4th edn (Beirut: Dar al-Kutub al-Ilmiah, 2003)

Amin Abdullah, Dinamika Islam Kultural; Pemetaan Atas Wacana Keilsaman Kontemporer (Bandung: Mizan, 2000)

Asrul Muslim, 'Interaksi Sosial Dalam Masyarakat Multietnis', Jurnal Diskursus Islam, 1.3 (2013)

Bustami Saladin, 'Tradisi Merari Suku Sasak Di Lombok Dalam Perspektif Hukum Islam', Al Ihkam: Jurnal Hukum Dan Pranata Sosial, 8.1 (2013)

D. Myers, Social Psychology (New York: Mc Graw-Hill, 2005)

Drs. H. Then Makmur, 'The Head of Religious Affairs (KUA) of Praya Subdistrict', 2019

Elly M Setiadi \& Usman Kolip, Pengantar Sosiologi Pemahaman Fakta Dan Gejala Permasalahan Sosial: Teori, Aplikasi, Dan Pemecahannya (Jakarta: Kencana, 2011)

F.A Rohmah, 'Pengaruh Pelatihan Harga Diri Terhadap Penyesuaian Diri Pada Remaja', Humanitas (Jurnal Pskologi Indonesia), 1.1

Fath Zakaria, Mozaik Budaya Orang Mataram (Mataram: Yayasan 
Sumurmas Al-Hamidy, 1998)

Gde Suparman, Titi Tata Adat Perkawinan Sasak, Kepembayunan Lan Candrasengkala (Mataram: Lembaga Pembukuan dan Penyebaran Adat Sasak Mataram Lombok, 1988)

Graham C., Kinlockh, Ideology and the Social Science (Greenwoon Press, 1981)

Haslam, Alexander, Psychology in Organization (The Social Identity Approach) (New Delhi: Sage Publication, 2001)

Huda, Muhammad Johan N, 'Dinamika Pencapaian Identias Sosial Postif Atas Keistimewaaan Yogyakarta', Jurnal Pskologi Integratif, $2.1(2014)$

Jabal Tarik Ibrahim, Sosiologi Pedesaan (Malang: Universitas Muhammadiyah Malang, 2003)

John Ryan Bartholomew, Alif Lam Mim: Kearifan Masyarakat Sasak (Yogyakarta: Tiara Wacana, 2001)

Kamal Mukhtar, Azas Azas Hukum Islam Tentang Perkawinan (Jakarta: Bulan Bintang, 1994)

Klandermans, The Social Psychology of Preotes (Oxford: Blackwell, 1977)

L., Knapp, Interpersonal Communication and Human Relationship (Newton MA: Allyn And Bacon, 1984)

M. Bahauddin al-Qibbani, Al-Faqru Wa Al-Ghina Fi Al-Qur'an Al-Karim (Kairo: Muassasah Dar al-Sya'b)

M. Nur Yasin, 'Kontekstualisasi Doktrin Tradisional Di Tengah Modernisasi Hukum Nasional: Studi Tentang Kawin Lari (Merari') Di Pulau Lombok', Jurnal Istinbath, IV.1 (2006)

M. Rosenberg, Society and The Adolescent Self-Image (Pincestin NJ: Princeton University Press, 1965)

M.H. Guindon, Self Esteem Across The Lifespan (New York: Francis Group LCC, 2010)

Marjohan, 'An Investigation of Factors That Influences Decision and Their Relationship to Self-Esteem and Locus of Control Among Minangkabau Students' (University of Tasmania Australia, 1977)

Michael A Hogg \& D. Abrams, 'Social Motivation, Self Esteem Social Identity', in Social Identity Theory: Constructive Dan Critical Advance, ed. by D. Abrams \& M.A. Hogg (New York: Havaerster Wheatsheaf, 1990)

Muhamamd Harfin Zuhdi, Bias Gender Stratifikasi Perempuan Bangsawan Sasak Dalam Perkwainan Masyarakat Lombok Nusa 
Tenggara Barat (Jakarta, 2010)

Muhammad Abu Zahrah, Ushul Fiqh (Jakarta: Pustaka Firdaus, 2003)

Muhammad Dja'far, Etika Bisnis Islami Dalam Tataran Teoritis Dan Praktis (Malang: UIN Malang Press, 2008)

Muhammad Khalid Mas`ud, Islamic Legal Philosophy (Islamabad: Islamic Research Institut, 1977)

Muhammad Salim Mazkur, Madkhal Figh Al-Islam (Kairo: Dar alQaumiyyah, 1964)

Musthafa Said al-Khin, Al-Kafi Wa Al-Wafi Fi Ushul Al-Figh Al-Islami (Beirut: Muassasat al-Risalah)

Nadiyah Syarif al-Umari, Ijtihad Fi Al-Islam (Give: Muassasat alRisalah, 1981)

Nathaniel Branden, The Power of Self-Esteem (Florida: Health Communications, 1992)

Nofiardi, 'Marriage and Baganyi: Sociological Analysis of Culture in Dispute Resolution in Banuhampu District of Religious District', Al Ihkam: Jurnal Hukum Dan Pranata Sosial, 13.1 Juni (2018)

R.B. Burns, The Self Concept Theory, Measurement, Development and Behaviour (London: Longman Group, 1979)

Rasyid Hasan Khalil, Tarikh Tasyri' (Jakarta: Amzah, 2009)

Rusli Rutan, Self Esteem: Landasan Keperibadian (Jakarta: Proyek Peningkatan Mutu Organisasi dan Tenaga Keolahragaan Dirjen Olahraga Depdiknas)

Salma and Burhanuddin, 'Study of 'Urf on Rompak Paga Tradition in Luhak Lima Puluh Kota of West Sumatra', Al Ihkam: Jurnal Hukum Dan Pranata Sosial, 12.2 (2017)

Shiddiqi, Nouruzzaman, Fiqih Indonesia, Penggagas Dan Gagasannya (Yogyakarta: Pustaka Pelajar, 1997)

Slamet Abidin and Aminuddin, Fiqh Munakahat (Bandung: Pustaka Setia, 1999)

Soerjono Soekanto, Sosiologi Sebuah Pengantar (Jakarta: Rajawali Press, 2010)

Stanley Coopersmith, The Antecendents of Self Esteem (San Fransisco: Freeman Press, 1967)

Stephen Cotgrove, The Science of Sociology: An Introduction to Sociology (London: Gerge Allan \& Unwin, 1982)

Steven Fein \& S.J. Spencer, 'Prejudice as Self Image Maintenance: Affirming The Self-Through Derogating Others', Journal of 
Personal and Social Psychology, 73 (1997)

Suhaimi, 'Praktik Khitbah Di Madura Perspektif Hukum Islam Dan Hukum Adat', Al Ihkam: Jurnal Hukum Dan Pranata Sosial, IX.2 (2014)

Syawal, H., 'The Marriage Registration Officer in the Prapen SubDistrict', 2019

Tim Monografi Daerah NTB, Monografi Daerah Nusa Tenggara Barat (Mataram: Depdikbud, 1977)

Ustadz L. Tamim, 'Marriage Registrar', 2019

Wahbah Zuhaili, Al-Fiqh Al-Islāmi Wa Adillatuh (Damaskus: Dar al Fikr, 2010)

Wilis Srusayekti dan David A. Setiady, 'Harga Diri Terancam Dan Perliaku Menghindar', Jurnal Pskologi, 42.2 (2015)

Y. Cicilia Praswati, 'Pertikaian Kelompok Etnik Di Kalamantan Barat: Tinjauan Berdasarkan Teori Identitas Sosial', Jurnal Psikologi Sosial, 2003

Yusuf Qardawi, Awami Al-Sa'ah Wa Al-Murunah Fi Al-Syariah AlIslamiyah Bayna Al-Inzibath Wa Al-Infirat (Kairo: Dar al-Tauzi wa al-Nasyr al-Islamiyyah, 1994)

Zainuddin Maliki, Narasi Agung Tiga Teori Sosial Hegemonik (Surabaya: LPAM, 2004)

Zaki, 'Tradisi Islam Suku Sasak Di Bayan Lombok Barat, Studi Historis Tentang Islam Wetu Telu 1890-1965' (UIN Sunan Kalijaga Yogyakarta) 